\title{
IMPROVING THE QUALITY OF DEMOCRACY IN INDONESIA: TOWARD A THEORY OF ACTION
}

\author{
R. William Liddle
}

In mainstream political science, most discussions of the quality of democracy, particularly in new democracies like Indonesia, highlight the performance of key institutions and procedures. Larry Diamond and Leonardo Morlino identify four of these: "(1) universal, adult suffrage; (2) recurring, free, competitive, and fair elections; (3) more than one serious political party; and (4) alternative sources of information." They continue: "Once a country meets these basic standards, further empirical analysis can ask how well it achieves the three main goals of an ideal democracy-political and civil freedom, popular sovereignty (control over public policies and the officials who make them), and political equality (in these rights and powers)-as well as broader standards of good governance (such as transparency, legality, and responsible rule)." ${ }^{1}$

Within this frame, this essay attempts to develop the rudiments of a theory of action that can empower scholars and activists to improve the quality of democracy in Indonesia and elsewhere. Following Robert Dahl, it argues that the basic obstacle to achieving the goal of political equality highlighted by Diamond and Morlino is market capitalism, an economic system that everywhere creates inequalities. To be sure, this is an old critique. Perhaps the most vigorous and long-lasting attack on capitalism was launched by Karl Marx in the nineteenth century. Nonetheless, contemporary Marxist

${ }^{1}$ Larry Diamond and Leonardo Morlino, "The Quality of Democracy: An Overview," Journal of Democracy 15,2 (2004): 21. 
analysts do not help us much to understand how to improve democracy. ${ }^{2}$ Mostly they tell us to throw out the baby, democracy, together with the bath water, capitalism. In reality, both need to be saved.

In this effort, the ideas of sixteenth-century political philosopher Niccolo Machiavelli are more useful than those of Marx. Machiavelli focused on the individual as an independent actor who creates, possesses, and deploys political resources. In the twentieth and twenty-first centuries, his framework has been brilliantly developed by several American political scientists. Each has contributed to the formulation of a theory of action that will help us better understand politics and improve the quality of democracy. Their contributions, with Indonesian applications, will be discussed below.

\section{Robert Dahl: Resource Inequality and Democracy}

In On Democracy, Robert Dahl summarized five key arguments about the relationship between market capitalism and democracy. ${ }^{3}$ First, throughout modern history, democracy has only endured in countries with capitalist market economies, never in countries with non-market economies. According to Dahl, this empirical finding is astonishing; in the social sciences there is almost never so strong an association between two factors.

Second, this relationship has an empirical foundation. In market economies, the main participants are individuals and private companies acting on their own, motivated by profit and loss incentives, without direction from a center. Following Adam Smith, Dahl argues that this incentive-regulated pattern of behavior produces highly efficient economies. Efficient economies in turn tend to grow quickly, reduce the percentage of the absolute poor, and produce economic resources that can be distributed to resolve conflicts among interest groups.

Economic growth also produces more economic resources available to create a literate and educated population, factors proven positive for democracy. Most importantly, economic growth tends to produce a property-owning middle class, which typically demands education, personal autonomy, individual freedom, rule of law, and participation in government. "The middle classes, as Aristotle was the first to point out, are the natural allies of democratic ideas and institutions." ${ }^{4}$

Conversely, a non-market economy is not only inefficient but tends to place most economic resources in a single set of hands, the hands of the government of the state. That monopoly is used by government officials to construct or defend authoritarian rule. The twentieth century's most prominent examples were the communist and fascist governments. Dahl reminds us that those governments were responsible for the murder of millions of their own people, something that has not occurred in democratic countries. Third, democracy and market capitalism are in continuous conflict while

\footnotetext{
${ }^{2}$ There are, to be sure, many variants of Marxism today, although the common thread is perhaps a materialist interpretation of history. This essay, as elaborated below, focuses on analysts who call themselves "critical theorists."

${ }^{3}$ Robert Dahl, On Democracy (New Haven, CT: Yale University Press, 1998).

${ }^{4}$ Ibid., p. 168.
} 
simultaneously shaping and reshaping each other profoundly. In Great Britain, toward the middle of the nineteenth century, capitalism as laissez-faire ideology succeeded in overcoming its competitors. But capitalism as an economic force had also created new economic interests, including labor unions demanding state intervention and regulation. At the beginning of the twentieth century, British workers created the Labour Party. With the building of modern economies, similar developments occurred in almost all European and overseas British states.

Dahl's argument: laissez-faire ideology is impossible to maintain in a democratic country. Logically, key market institutions need to be regulated by a body external to the market, the most effective of which is the state. Market competition, ownership of economic units, the implementation of contracts, the prevention of monopoly, and the protection of property rights all need the involvement of the state to work properly. Empirically, we observe that laissez-faire ideology has never been implemented in a democratic country.

Moreover, markets simultaneously provide benefits and create losses. In a democracy, individuals and groups who feel disadvantaged will demand reform of that characteristic or element of the market thought responsible for their losses. The result everywhere is economic policies and rules that regulate the economy and reduce market freedom. As evidence, Dahl lists several categories of economic behavior that are regulated in the United States, the state ostensibly "famous for its commitment to market capitalism." ${ }^{5}$

Dahl's fourth argument contends that market capitalism limits the potential for high quality democracy by creating important inequalities in the distribution of political resources. Political resources "include everything to which a person or a group has access that they can use to influence, directly or indirectly, the conduct of other persons." ${ }^{\prime \prime}$ As potential resources, Dahl lists "physical force, weapons, money, wealth, goods and services, productive resources, income, status, honor, respect, affection, charisma, prestige, information, knowledge, education, communication, communications media, organizations, position, legal standing, control over doctrine and beliefs, votes, and many others." Among these possibilities, in a modern democracy, the most important and, at the same time, the most vulnerable to the depredations of market capitalism are wealth, income, status, prestige, information, organization, education, and knowledge. ${ }^{?}$

Dahl's fifth and final argument describes an ineluctable present-and-future tension that constitutes a powerful irony. On the one hand, the creation of democratic institutions was made possible and is undergirded by market capitalism. Everywhere and for centuries, authoritarian governments have collapsed when land-owning classes (who control almost all the political resources in pre-modern societies) and ordinary farmers (who have few political resources) are replaced by a more complex class structure. Rural politics, which puts two main classes in opposition to each other, is replaced by urban politics, which empowers many groups. The politics of the

\footnotetext{
${ }^{5}$ Ibid., p. 175.

${ }^{6}$ Ibid., p. 177.

${ }^{7}$ Ibid.
} 
illiterate is replaced by the politics of the educated. Knowledge and organization become important political resources.

On the other hand, capitalism as the creator of many inequalities becomes the main obstacle to the further development or deepening of democracy. Here is the great irony. It is precisely those political resources that are most valuable in citizens' struggles for their rights and interests that are distributed unequally by market capitalism. This reality only becomes visible, however, after the basic electoral and governmental institutions and interest and party organizations of modern democracy have been established.

\section{Three Implications for Scholars of Indonesia}

Dahl's conclusions have three key implications for scholars of contemporary Indonesia. First, the political resources in the hands of those who would like to improve the quality of Indonesian democracy are extremely limited. Other players, though small in number, are vastly superior in amount and weight of resources. Even so, democracy as the best political system and the capitalist market as the best economic system are both highly valued by most Indonesians (as reflected, for example, in opinion surveys). ${ }^{8}$ At the same time, citing Isaiah Berlin's value pluralist terms, we note that economic and political freedom may be incommensurable. ${ }^{9}$ If the two systems, capitalism and democracy, sometimes clash, democratic theorists and those who would like to improve the quality of Indonesian democracy must live with that reality.

Second, recognition of this resource imbalance requires us to reassess our understanding of the bases of political action. Analysis of resources cannot be separated from conceptualization of the political system as a whole, including demand-making, governmental formulation of policy responses, decision-making, and policy implementation. In other words, a theory of action is needed that can conceptualize the role of the actor in the political system while placing that role in the context of the constraints that limit action and the opportunities that facilitate it. The concepts of constraints and opportunities will be elaborated below.

Third, scholars of contemporary Indonesia are urged by Dahl, again implicitly, to study the ways in which the key political resources he has identified can be developed and distributed as widely and democratically as possible. This third task is more comprehensive and long term. ${ }^{10}$ This essay focuses on the first and second, the recognition of a resource imbalance and the formulation of a theory of action to reduce the level of imbalance.

\footnotetext{
${ }^{8}$ R. William Liddle and Saiful Mujani, "Indonesian Democracy: From Transition to Consolidation," in Democracy and Islam in Indonesia, ed. Alfred Stepan and Mirjam Kunkler (New York, NY: Columbia University Press, 20013), pp. 24-50.

${ }^{9}$ Isaiah Berlin, The Crooked Timber of Humanity (London: Fontana Press, 1991).

${ }^{10}$ The most promising research in this area is being conducted by Amartya Sen and associates under the label of the "capabilities approach." See Amartya Sen, Development as Freedom (New York, NY: Anchor 1999); see also R. William Liddle et al., Memperbaiki Mutu Demokrasi di Indonesia: Sebuah Perdebatan (Jakarta: Yayasan Wakaf Paramadina, 2012), pp. 37-40.
} 
In my view, the conclusions to be drawn from Dahl's analysis are clear. Scholars need to develop a theory of action that recognizes but does not exaggerate the influence of material resources in achieving political equality in modern democracies. Such a theory should specify the factors constraining and facilitating action by individuals and groups that want to reduce political inequality and thereby improve the quality of democracy. And it should further specify and elaborate how to develop and distribute those resources most critical to increasing equality.

Unfortunately, in Indonesia and elsewhere, there are influential analysts who have drawn other conclusions. The analysts I have in mind call themselves "critical theorists," connoting hostility to the capitalist organization of domestic and international economies. In their view, the institutions of democracy constitute a mere mask obscuring the power of the wealthy. According to such theorists, those institutions reflect not rule by the people, but instead by a small wealthy elite, upper class, or oligarchy. Even in the strongest democracies, these elites will prevail.

The argument posed by critical theorists assumes that material wealth is virtually the only potent resource in politics. In this respect, they differ with Dahl, who regards wealth as important but only one of many resources mobilizable in politics. The original source of the critical theorists' position is the mid-nineteenth-century theory of Karl Marx, developed to explain the social and political impact of early industrialization.

For Marx, the principal actor in history is not the individual, but social classes based on control of property. Social change is shaped and moved by class conflict. Not all Marxists today focus primarily on classes or class conflict, though that theme remains prominent. Perhaps the defining feature of twenty-first-century Marxism is an unmitigated and implacable hostility to capitalism and all its works. A contemporary example, which also retains the class focus, is the critique mounted by widely cited anthropologist David Harvey of "neoliberalism," which he claims "provide[s] a benevolent mask full of wonderful-sounding words like freedom, liberty, choice, and rights, to hide the grim realities of the restoration or reconstitution of naked class power, locally as well as transnationally, but most particularly in the main financial centers of global capitalism." ${ }^{11}$

In Indonesia, critical theory has been developed most fully and persuasively by Richard Robison and Vedi Hadiz. ${ }^{12}$ Their book describes not a classical Marxist confrontation of bourgeoisie and proletariat but rather the way in which certain

\footnotetext{
${ }^{11}$ David Harvey, A Brief History of Neoliberalism (Oxford: Oxford University Press, 2005), p. 119. "Neoliberalism" is defined by Harvey as "a theory of political economic practices that proposes that human well-being can best be advanced by liberating individual entrepreneurial freedoms and skills within an institutional framework characterized by strong private property rights, free markets, and free trade" (p. 2). In fact, the concept, "neoliberalism," is a polemical term of abuse employed by Marxist scholars like Harvey. As far as I can determine, no scholars use it to label their own approach. Substantively, the Marxist claim is that the current small government approach of classical liberals inspired by Friedrich von Hayek, The Road to Serfdom (Chicago, IL: University of Chicago Press, 1994), is being used to justify world domination by capitalist elites. In truth, Hayekian liberalism is only one of many contemporary economic theories in play, and has been increasingly challenged since the 2007-08 global financial crisis by more interventionist theories.

${ }^{12}$ Richard Robison and Vedi Hadiz, Reorganising Power in Indonesia: The Politics of Oligarchy in an Age of Markets (London and New York, NY: RoutledgeCurzon, 2004).
} 
Indonesian business and governmental elites responded $\grave{a}$ la Harvey to the opportunities and constraints of the global capitalist order. According to Robison and Hadiz, a "complex oligarchy" was formed during Suharto's New Order. A complex oligarchy is defined as "a system of government in which virtually all political power is held by a very small number of wealthy ... people who shape public policy primarily to benefit themselves financially ... while displaying little or no concern for the broader interests of the rest of the citizenry." ${ }^{13}$ When formed, this Indonesian oligarchy consisted of three elements: state officials, "politico-business families," and business conglomerates.

According to Robison and Hadiz, the complex oligarchy is still in power today, even though the authoritarian New Order regime fell in 1998 and was replaced with formally democratic institutions. The authors also deny that decentralization has had any impact on the quality of Indonesian democracy. Those in power now, both in the center and the regions, more than a decade after reformasi (reform, the Indonesian term for the democratic transition begun in 1998), are still individuals or their representatives from the three elite groups listed above.

Robison and Hadiz's prediction is pessimistic: "[T]he possibility that cohesive reformist parties might emerge from the wreckage, driven by a coherent agenda of market liberalism rather than being swallowed in a system of power relations embedded in the pursuit of rents appears even more remote than ever ... [This means] a system of democratic rule where the state apparatus will provide some form of order in which oligarchies rather than markets will prevail." ${ }^{14}$

Long-time observers of Indonesian politics can readily understand the appeal of Robison and Hadiz's argument, both as empirical observation and as moral complaint. During the New Order, it was reasonable to believe that many high officials violated their oath of office in return for material reward. It also seemed apparent that officials' family members and private businesspeople were part of a patron-client system that profited them at the expense of the nation and the state. Even so, the argument of critical theorists is incorrect, either as moral complaint or empirical analysis. As moral complaint, it is incomplete. Of course, it is undeniable that many officials, members of the families of officials, and businesspeople with government connections profited corruptly during the New Order. Nonetheless, the nearly 8 percent growth rate maintained for more than a quarter century benefited the majority of the population. This history has been well told by several economists, including Anne Booth, ${ }^{15} \mathrm{Hal}$ Hill, ${ }^{16}$ and Peter Timmer. ${ }^{17}$

Empirically, the ruler of the New Order was not an oligarchy but a single dictator, Suharto. All important decisions were taken by Suharto himself to realize many different objectives, probably first and foremost the perpetuation of his own rule. The

\footnotetext{
${ }^{13}$ Ibid., p. 16 , note 6.

${ }^{14}$ Ibid., p. 265.

${ }^{15}$ Anne Booth, ed., The Oil Boom and After: Indonesian Economic Policy and Performance in the Soeharto Era (Singapore: Oxford University Press, 1992).

${ }^{16}$ Hal Hill, The Indonesian Economy since 1966 (Cambridge: Cambridge University Press, 1996).

${ }^{17}$ Peter Timmer, "The Road to Pro-Poor Growth: The Indonesian Experience in Regional Perspective," Bulletin of Indonesian Economic Studies 40,2 (2004): 177-207.
} 
so-called oligarchic elements of the New Order acted at once as a support base for Suharto and an instrument or political resource deployed by him. Without an appreciation of Suharto's role as self-conscious ruler, it is impossible to understand the ebbs and flows in the fortunes of particular economic groups during the New Order and the ways in which those shifts affected the larger economy and polity. ${ }^{18}$ Also important were a number of other resources not emphasized by Robison and Hadiz, most critically the armed forces, the coercive resource that enabled Suharto to keep his grip on his office for thirty-three years.

At the very least, it is incumbent upon scholars who employ abstract constructions-such as complex oligarchy, but also mainstream political science variables like interest groups, social movements, and religious beliefs-rather than the actions of concrete individuals as their independent or dependent variables to specify the nature of the evidence that persuades them and might persuade others of the validity of their claims. In the case of Suharto's New Order, for example, it is epistemologically much easier in at least three senses to provide broadly acceptable evidence for the proposition that Suharto or the relevant minister in each case promulgated a particular economic policy rather than to show that an oligarchy did it. If one focuses on the policies of Suharto and his state officials, then, first, the act will have been publicly reported. Second, the impact on others of the act is readily traceable. Third, questions of collusion, division of responsibility, and so on do not arise if claims are made only about individual human actors. These concerns are not raised in the critical literature on Indonesia.

Of course, as individuals, state officials (including armed forces officers), the families of officials, and private businesspeople had their own objectives, including objectives that could be realized through favorable government action. Throughout the New Order, most of these individuals seem to have been relatively satisfied that their demands were receiving a sufficient response. The evidence: there were few individuals, not to mention significant interest groups, who rebelled or broke their relationship with Suharto.

That fact does not, however, imply that those groups ruled the country. They supported the New Order because Suharto served their interests. Their political resources-including wealth, status, prestige, information, organization, knowledge, and positions-were mobilized by Suharto to establish and defend his rule. No more than that.

That system of rule changed dramatically after May 1998. Since reformasi, there have been thousands of rulers, that is, the presidents, governors, district heads, and mayors in the executive branch, plus the legislators in the center and the regions. In Weberian terms, the basis of authority of the New Order, personal rule (in that respect not different from Sukarno's Guided Democracy), is now legal-constitutional rule. Elective governmental office has become an autonomous and powerful political resource. It is difficult to imagine a more fundamental political transformation.

\footnotetext{
${ }^{18}$ See, for example, Thomas Pepinsky's analysis of the political economic causes of the fall of the New Order. Thomas Pepinsky, Economic Crises and the Breakdown of Authoritarian Regimes: Indonesia and Malaysia in Comparative Perspective (Cambridge: Cambridge University Press, 2009).
} 
Through the amendment process, the 1945 Constitution, previously manipulated to maintain two authoritarian rulers in power, has become the solid foundation of a modern presidential democracy. No less important, Laws 22/1999 and 25/1999 concerning regional government have laid the legal foundation for the decentralization of authority, including its all-important financing, channeling that authority to the provinces, districts, and municipalities. Presidents, governors, district heads, and mayors are now directly elected by the people.

Of course, that transformation does not mean that political demand-making by diverse interest groups has disappeared or even decreased after reformasi. What has happened in Indonesia was described clearly by Dahl when he wrote the following about European industrialization in the eighteenth century and later. "Democracy and market-capitalism are locked in a persistent conflict in which each modifies and limits the other." ${ }^{19}$

On the one hand, support for economic liberalization, which found its initial adherents and application during the New Order in the technocrats led by Professor Widjojo Nitisastro, has strengthened and even become dominant in state policymaking since the fall of Suharto. President B. J. Habibie (during the New Order a notorious state protectionist on behalf of his aircraft industry) and his successors, including the current President Susilo Bambang Yudhoyono (SBY), have all maintained the macroeconomic policies pioneered by Suharto. Nonetheless, economic groups that have not benefited from these policies have lobbied hard against them. Sometimes they use the newly opened democratic channels, but they also continue to rely on their old connections and resources, engaging in bribery and other illicit means.

For Robison and Hadiz, this mixing of politics and markets proves that the New Order oligarchy has come back to life. For the future, "a coherent agenda of market liberalism" will likely be "swallowed in a system of power relations embedded in the pursuit of rents." ${ }^{20}$ For Dahl, and me, this mixing is normal and unavoidable. There has never been a coherent agenda of market liberalism pursued by a democratic government because that agenda is always disrupted by the demands of those who have been disadvantaged by market capitalism and therefore sought rents (defined by neoclassical economists as payments for goods and services that are determined by non-market forces). The evidence for this is hard to miss in Indonesia in the form of legal subsidies distributed to many different groups of producers and consumers, most notably and controversially fuel oil consumers. According to economists, rents make markets less efficient. Without denying the economists' conclusions, which are accurate depictions of outcomes in the world constructed by their models, Dahl emphasizes that in the actually existing world, rents are the natural and ineluctable result of the marriage of democracy and market capitalism.

In sum, what has occurred post-reformasi in Indonesia is not the continuation of a complex oligarchy but instead a process of governmental fragmentation on the political side and market-capitalist continuity in the economy. Beginning in 1999 and continuing since that time, the rulers of the country have been chosen democratically.

\footnotetext{
${ }^{19}$ Dahl, On Democracy, p. 173.

${ }^{20}$ Robison and Hadiz, Reorganising Power in Indonesia, p. 265.
} 
From Dahl we know that market capitalism has multiple effects on democracy. The economic, social, and political policies of the New Order created or augmented several political resources held by members of society, as individuals and as groups. Those individuals and groups now act in the democratic system that they themselves have built. At the same time, throughout and after the New Order, the distribution of political resources has never been equal. Today, this inequality represents what is probably the biggest challenge to the quality of democracy in Indonesia.

More recent writings by Hadiz, ${ }^{21}$ Hadiz and Robison, ${ }^{22}$ and Jeffrey Winters ${ }^{23}$ do not add complexity to this picture. Hadiz's Localising Power in Post-Authoritarian Indonesia is an unrelievedly negative portrayal of post-decentralization politics in North Sumatra and East Java. Moreover, his evidence is entirely illustrative and by example. No attempt is made to define systematically leadership characteristics that would enable him or his readers to weigh which leaders are more and which less representative and accountable to local voters. ${ }^{24}$ Hadiz's conclusion repeats the themes of his and Robison's earlier work: "This book has shown that the main contenders in the contest in Indonesia are essentially shifting locally-based coalitions of predatory power rooted in the now demised [sic] New Order." ${ }^{25}$ Moreover, there is no way out, according to Hadiz, certainly not via the "good governance" programs supported by international donors or the actions of local reformist politicians. The former are dismissed as technocratic know-nothings and tools of "neoliberal" capital, while the latter are characterized as "goons and thugs." 26

Jeffrey Winters's understanding of oligarchy is more narrowly conceptualized and ultimately even less persuasive than Robison and Hadiz's arguments. The focus is not on classes or the components of a complex oligarchy but rather on extremely wealthy individuals and the defense of their wealth. Other power resources beyond great material wealth-"formal political rights, official positions, coercive power, mobilizational power' - are in principle taken into account. ${ }^{27}$ The extent to which lesser amounts of wealth count as a political resource in a democracy is, however, totally left out. This, as we have seen, is a key variable for Dahl, who argues convincingly that economic development creates not just great wealth but a complex pattern of economic concentration and dispersion that both supports and challenges democracy. $^{28}$

\footnotetext{
${ }^{21}$ Vedi Hadiz, Localising Power in Post-Authoritarian Indonesia (Stanford, CA: Stanford University Press, 2010).

22 Vedi Hadiz and Richard Robison, this volume.

${ }^{23}$ Jeffrey Winters, Oligarchy (Cambridge: Cambridge University Press, 2011); Jeffrey Winters, this volume.

${ }^{24}$ Two systematic studies that do enable the reader to identify more and less successful cases of leadership at the local level are Ryan Tans, Mobilizing Resources, Building Coalitions: Local Power in Indonesia (Honolulu, HI: East-West Center, 2012); and Christian von Luebke, "The Political Economy of Local Governance: Findings from an Indonesian Field Study," Bulletin of Indonesian Economic Studies 45,2 (2009): 201-30.

${ }^{25}$ Vedi Hadiz, Localising Power in Post-Authoritarian Indonesia, p. 172.

${ }^{26}$ Ibid., p. 14

${ }^{27}$ Winters, this volume; Winters, Oligarchy, pp. 11-20.

$2 s$ "Democracy refers to dispersed formal political power based on rights, procedures, and levels of popular participation. By contrast, oligarchy is defined by concentrated material power based on enforced claims or rights to property or wealth." Winters, Oligarchy, p. 11, emphases in the original. Moreover, "ending oligarchy is impossible unless the power resource that defines oligarchs-concentrated wealth-is
} 
In Winters's view, Indonesian politics is dominated by the extremely wealthy. "The argument is not that all Indonesian politics reduce to oligarchs and oligarchy. Rather, it is that from a power resource perspective, oligarchs are tremendously influential actors within Indonesia's political economy, that they were already powerful during Soeharto's New Order, and that the transition to democracy does not constitute a significant disruption or even diminution of their power." ${ }^{29}$

Winters makes no systematic effort to link causally his main independent variable, material power resources held by a small number of extremely rich people, with policy outputs or outcomes. "The politics of wealth defense by materially-endowed actors" 30 is a near-tautological definition of oligarchy. Most of Oligarchy's long discussion of wealth accumulation and its defense in Indonesia retells a well-known story. ${ }^{31}$ No one denies that Suharto accumulated great wealth, for both personal and political purposes, and allowed others to do so as well, under his tight control. Nor would anyone deny that wealth accumulation and defense by wealthy individuals continues to this day, as it does in all capitalist market economies, where the whole point of being a capitalist is to build one's business.

What is missing from Winters's interpretation is serious consideration of other variables and what effect they might have had on New Order politics or might be having on today's democracy, which he characterizes both as criminal $^{32}$ and untamed. ${ }^{33}$ Potentially positive trends in the development of civil society or of the rule of law that might provide counterweights to material power get particularly short shrift in Oligarchy. One of the most important political developments in recent years, in my view, is the repeated and indeed growing intervention by civil society in defense of the Komisi Pemberantasan Korupsi (KPK, Corruption Eradication Commission). In 2012 alone there were two instances of successful popular mobilization on behalf of the KPK, the "coins for the KPK" movement in June and the support for the KPK against attempts by the National Police to undermine its autonomy in October. ${ }^{34}$

Finally, a favorite rhetorical device of both Winters and Hadiz is to assert that supposedly reformist politicians have feet of clay. The 2012 gubernatorial election success in Jakarta of Joko Widodo, the reformist mayor of Solo, "was possible only because he had major oligarchic backers. ${ }^{235}$ For Hadiz, the performance of the district head of Jembrana, Bali-praised by other observers-is diminished if not negated by the fact that this official was "widely believed to have won power by bribing members

dispersed. This has happened many times in history ... However, it has never been successfully attempted as a democratic decision." Ibid., p. 285.

${ }^{29}$ Winters, this volume.

${ }^{30}$ Winters, Oligarchy, p. 7.

${ }^{31}$ Ibid., pp. 139-93.

${ }^{32}$ Ibid., p. 142.

${ }^{33}$ Ibid., pp. 181ff. To his credit, Winters does recognize that "a campaign to tame oligarchs ... is an achievement that can improve the absolute welfare of average citizens," though he still concludes pessimistically to the effect that "even if the relative gap between them and oligarchs widens rather than narrows" (p. 285).

34 "Masyarakat Menyumbang," Kompas, June 27, 2012; Tempo, October 8-14, 2012; Tempo, October 15-21, 2012; and Tempo, October 22-28, 2012.

${ }^{35}$ Winters, this volume. 
of the local parliamentary body that voted him into office ..." ${ }^{36}$ These arguments are not the product of a systematic analysis of the range of variables potentially constraining and enabling the behavior of political actors. They are polemical pointscoring.

\section{Developing a Theory of Action}

How should scholars of Indonesian democracy respond to Dahl's challenges while avoiding the conceptual and empirical errors made by the oligarchy theorists? To repeat, we need a theory of action that is capable of explicating the role of the actor in context while appreciating that the distribution of political resources is highly unequal. In particular, we need to specify and elaborate the factors constraining and facilitating political action to reduce this inequality. For this purpose, we can learn much from the clearing first cut nearly five hundred years ago by the political philosopher Niccolo Machiavelli and later expanded by four American political scientists: Richard E. Neustadt, James MacGregor Burns, John W. Kingdon, and Richard J. Samuels.

From its day of publication, Machiavelli's The Prince ${ }^{37}$ has been notorious as a handbook of evil for unscrupulous politicians. But The Prince could not have endured, indeed, become a classic, for nearly half a millennium if its advice was only that. Three positive contributions of The Prince resonate today. First, Machiavelli inspired future thinkers to separate the actual from the ideal. Mid-twentieth-century empirical political scientists praised Machiavelli because he affirmed their intent to develop a genuinely scientific political science. Second, rereading Machiavelli reminds us, against Machiavelli's purpose, that the tension between private and public morality is ineluctable. Morality for a politician, including in modern democracies, differs from individual private morality.

Third, and most important, Machiavelli offered an elegant new framework, consisting of the concepts virtu and fortuna, for empirical political analysis. Virtu means skill or masculinity, from the word vir, male, in Latin. Its meaning is different from "virtue" in English, which denotes high moral purpose. In the language of this essay, virtu is considered a collection of resources held by a person or that can be created, mobilized, and deployed to achieve his or her goals as a political actor. Examples of political resources mentioned by Machiavelli are diverse. Among other things he noted: intelligence, strategic and tactical courage, conscientiousness, firmness, a reputation for a willingness to forgive, support from one's own people, support by the leader of a neighboring state, and ability to choose aides and to read the signs of the times. Also, of course: cunning and readiness to lie and to use force in a calculated and cold-blooded fashion.

Fortuna means chance or luck, but in the sense of natural and social conditions and events to which actors respond, without the implication that necessity or fate are involved. Two well-known explications from Machiavelli himself: (1) "Fortuna seems to be the arbiter of half our actions, but she does leave us the other half, or almost the

\footnotetext{
${ }^{36}$ Hadiz, Localising Power in Post-Authoritarian Indonesia," p. 29.

${ }^{37}$ Niccolo Machiavelli, The Prince, trans. Peter Constantine (New York, NY: Random House Modern Library, 2008 [first published in 1527]).
} 
other half, in order that our free will may prevail;" 38 and (2) "It is better to be impetuous than cautious, because Fortuna is a woman, and if you wish to dominate her you must beat and batter her. ${ }^{\prime 39}$

In our time, Machiavelli's approach to the study of political leadership has been applied by the political scientists Richard E. Neustadt and James MacGregor Burns (of course, after rejecting his views on violence and women). The first edition of Presidential Power, ${ }^{40}$ Neustadt's most influential book, was published several months before John F. Kennedy's presidential inauguration. After Kennedy's death, Neustadt founded the Harvard Kennedy School (HKS), today the most celebrated public policy graduate school in the United States.

In Presidential Power, Neustadt extends Machiavelli's approach to the analysis of American presidents in the modern era (the "modern era" is Neustadt's term, which he uses to emphasize the importance of time and place in political analysis). For Neustadt, the power to persuade is the chief political resource a president can deploy. The success of his programs and policies is highly dependent on his willingness and capacity to persuade three types of people: members of his own government; Washington society (especially Congress and the Supreme Court); and the voting public (including the press and public opinion survey institutions). In Neustadt's words: "The essence of a president's persuasive task is to convince such men that what the White House wants of them is what they ought to do for their sake and on their authority." ${ }^{\prime 1}$

Based on his research on three presidents-Franklin Roosevelt, Harry Truman, and Dwight Eisenhower-Neustadt argues that there are five factors that determine the success or failure of a president's policy or program. The president himself must be fully involved in the process of decision-making on any specific issue. His words must be unambiguous. His view must be publicized widely. The instruments and resources that are available for implementation must be up to the task. And the recipients of his instructions must accept his authority and legitimacy in terms of that particular policy or program.

This is a simple and seemingly obvious list of factors. Nonetheless, in the hands of the expert and experienced analyst Neustadt, employing them as a conceptual framework deepens our understanding of the meaning and causes of presidential achievement in America. In Indonesia, there has so far been no comparable study of any of Indonesia's democratic presidents. Abdurrahman Wahid and Megawati Sukarnoputri's relatively short presidencies, under the quasi-parliamentary institutional rules prevailing during their tenures, are probably less suitable for a Neustadt-style analysis than that of the two-term, directly elected SBY.

What such a study might show is that, in comparison to the records of all three of his non-democratic predecessors-Sukarno, Suharto, and Habibie-there have been

\footnotetext{
${ }^{38}$ Ibid., p. 115.

${ }^{39}$ Ibid., p. 118.

${ }^{40}$ Richard E. Neustadt, Presidential Power and the Modern Presidents: The Politics of Leadership from Roosevelt to Reagan (New York, NY: The Free Press, 1990 [first published in 1960]).

${ }^{41}$ Ibid., p. 30.
} 
few policy areas in which SBY has been fully involved, let alone unambiguous in his policy position, and he has not publicized his views widely or paid attention to implementation or to whether his constituents accepted his legitimacy in that particular policy area. ${ }^{42}$ In the economy, SBY has been criticized for failing to deal with burgeoning fuel subsidies that have several times threatened to overwhelm the state budget. He has arguably failed to formulate, let alone implement, a broad plan for infrastructure development, according to most economists a prerequisite for future growth. In social affairs, he is criticized for failing to protect a range of religious minorities, including Christians, Shi'ites, and Ahmadis. In foreign relations, he has carried out few significant initiatives.

How to explain this lackluster performance, especially when we recall that this is a president who was directly elected twice by large majorities-in 2009, by 61 percent in the single-round presidential election? In a democracy, popular support is typically the single most important resource that can be deployed by an elected official to achieve his or her goals. In the hands of political parties and civil society groups, it is also a key resource for reducing the political inequality created by capitalism in Dahl's account. In SBY's case, the puzzle appears to be why he has not made better use of that resource. One possible answer, which calls for systematic research to test it, is the relative organizational weakness of parties and interest groups. With regard to fuel subsidies, for example, the mass constituency that can be mobilized to support promarket reform has arguably been much weaker than the defenders of the status quo.

Neustadt specifies three target audiences for presidential persuasive power, one of which is the voting public. In Indonesia, systematic studies of voting behavior have been pioneered by Saiful Mujani, who wrote the first scientific study of Indonesian voting behavior after reformasi. ${ }^{43}$ For the first time in Indonesian history, several large national random-sample surveys using up-to-date methodology have been conducted since 1999.

Analysis of this data shows that the factors that have most influenced the voter's choice in parliamentary and presidential elections since 1999 have been psychological and political economy factors, including voters' perceptions of the national economic condition. If his or her perception is positive, the voter tends to choose the incumbent president or governing party; if negative, the voter tends to choose the opposition candidate or party. This finding directly contradicts the conventional wisdom of the 1950s (based in part on anthropological data) that most voters in Indonesia are influenced by religious, regional or ethnic, and social class solidarities.

In consequence, analysts and players today have an understanding of Indonesian electoral politics that is much more accurate, sophisticated, and reliable than before modern surveys were conducted. President SBY, for example, is known to place a high degree of trust in the findings of pollsters and to have used them to help define his election campaign themes and even his choice of a running mate in 2009. Excessive sensitivity to poll-based evaluations of his actions may also help to explain his

\footnotetext{
${ }^{42}$ But see the discussion later in this article about Djayadi Hanan analysis of SBY's leadership, pp. xx.

${ }^{43}$ Saiful Mujani, R. William Liddle, and Kuskridho Ambardi, Kuasa Rakyat (Jakarta: Mizan, 2012).

${ }^{44}$ Ibid., Chapter 3.
} 
lackluster performance, as noted above. We may hypothesize that he has often failed to act in a particular policy area because of a calculation that public opposition to his preferred policy in that area is too great. Again, this points to the value of future systematic research examining the effect on elected officials of pressure from mobilized groups in society.

James MacGregor Burns's most influential book, Leadership, was published almost two decades after Neustadt's. ${ }^{45}$ By the late 1970s, the times had changed dramatically in America, where political activists had mobilized to oppose discrimination against African-Americans and the war in Vietnam. Leadership was Burns's response. His world view was more to the left than that of Neustadt, placing greater emphasis on the necessity of conflict to bring about social change. Moreover, Burns's approach was more psychological and moralistic than political scientific in the empirical sense that I have characterized as the mainstream of the discipline.

Burns introduced two new analytical elements: the concept of followership as inseparable from leadership; and the division of leadership into two prominent types, transactional and transforming. Transactional leadership, the much more common form, he defined as the exchange of political resources in the form of goods and services, including votes in elections, between leaders and followers. Both sides obtain something valuable from the transaction, and the society may also benefit. But in transactional leadership there is no higher objective that binds together leaders and followers in the pursuit of a higher moral purpose. This second type of leadership Burns called transforming.

Burns's contribution to the development of a theory of action is impressive and promising. The understanding of followership as a concept that highlights the voters' continuing interaction with leadership can help us to understand the rise and fall of social movements that potentially reduce political inequality. In Indonesia, Burns's followership concept can be used to investigate all forms of social and political movement, from the early nationalist period to the present. The relatively successful defense today of the KPK by civil society groups, discussed above in my critique of the oligarchical perspective, is an obvious topic for further research. Another example is the interaction between leaders and followers within Islamic movements, with their generally high level of ideological commitment. What difference do leaders make in such a context? A valuable study might be conducted of former Masjumi leader Mohammad Natsir's leadership during the New Order in laying the foundation of today's Islamist resurgence. The Islamist organizations PKS (Partai Keadilan Sejahtera, Prosperous Justice Party), HTI (Hizbut Tahrir Indonesia), and FPI (Front Pembela Islam, Islamic Defenders Front) may also be usefully compared in these terms. Have individual leaders played a relatively small role in PKS and HTI but a dominant one in FPI, and, if so, what have been the consequences for these movements?

Indonesia has by now had enough presidents (though of course not all democratic) to enable scholars to compare their levels of achievement in terms of Burns's framework. Sukarno was arguably a transforming leader until 1949, after which he failed both as a transforming and transactional leader. Far more than any other leader,

${ }^{45}$ James MacGregor Burns, Leadership (New York, NY: Harper Perennial Political Classics, 2010 [first published in 1978]). 
as he engaged with millions of followers, he shaped his fellow Indonesians' pan-ethnic, pan-religious identity and their stance toward the outside world. His subsequent efforts to pump Third World populism into that identity and to maintain himself in power transactionally through balancing PKI and army support led, perhaps inevitably, to economic decline and political instability, if not to the cataclysm of 1965. During Guided Democracy, Sukarno's unique deployment of the combined political resources of charisma and coercion arguably left most Indonesians less politically equal to the established elites than they had been in the 1950 s.

During the New Order, Suharto succeeded in transforming the Indonesian economy, but his successes came at a high price, as they increased political repression and inequality. Measured in Burns's frame, Suharto was not a genuine leader, that is, he did not build and learn from a genuinely engaged followership from below but instead relied on heavily managed elections and "floating masses." Under the leadership of B. J. Habibie, Indonesian politics was transformed from dictatorship to democracy. The result was a huge increase in political equality, but the actions of Habibie himself were more transactional than transforming, which perhaps helps explain why he was not elected president in his own right in $1999 .{ }^{46}$ Abdurrahman Wahid, Megawati Sukarnoputri, and Susilo Bambang Yudhoyono have been at best transactional presidents. Their successes and failures must be measured by the extent to which, given the constraints and opportunities of their time, they adopted strategies and tactics that improved the quality of the democratic institutions they inherited and thus increased political equality.

Two substantial objections may be raised to Burns's approach. First, his moral compass is distorted. Like many Left intellectuals of his time, Burns is too quick to forgive brutal behavior in the name of higher purpose. ${ }^{47}$ Second, and analytically more relevant, Burns demands too much from us as ordinary citizens of large modern states. His approach evokes normative theories of participatory democracy, in which citizens participate directly in policy making, and deliberative democracy, in which citizens are urged to deliberate until a consensus is achieved. Initially inspired by Athenian democracy, these ideas probably are most applicable today to small social groups or communities. In Indonesia, they might give new life to discussions about village democracy, which many Indonesians value positively but believe has been undermined by modernization. Providing more resources to village government and social institutions might be one way to reduce political inequality.

The approach of John W. Kingdon differs considerably from that of Neustadt and Burns, who focus exclusively on the most important national-level actors like presidents and their most critical decisions. Neustadt and Burns are also often dismissed as unscientific by mainstream political scientists. Their concepts are ostensibly too high level, grand, vague, and opaque; difficult to turn into operational variables that can be tested in the form of empirical hypotheses. From the title alone,

\footnotetext{
${ }^{46}$ R. William Liddle, "Indonesia's Democratic Transition: Playing by the Rules," in The Architecture of Democracy, ed. Andrew Reynolds (Oxford: Oxford University Press, 2002), pp. 373-99.

${ }^{47}$ Of course, it is not only observers from the anti-capitalist Left who have a one-sided view of their times. I, myself, conducting research from the center-left, have not yet written in a balanced way about the leadership of Suharto, who was arguably responsible both for the mass murders of 1965-66 and the subsequent economic development that has so benefited the Indonesian people.
} 
Agendas, Alternatives, and Public Policies, it is clear that Kingdon's focus is on practical problem solving. ${ }^{48}$ The actor only appears as a potential cause of a policy outcome in his systematic comparison of twenty-three cases of decision-making in the health and transportation sectors, most of them during the US presidency of Jimmy Carter (197781).

The potential value of Agendas, Alternatives, and Public Policies for developing a democracy-relevant theory of action is enormous, greater perhaps than the work of any other modern scholar discussed in this essay. Kingdon's principal findings are as follows:

- The actors with the greatest influence on outcomes are the elected politicians and others visible to the researcher, not hidden actors behind the screen.

- Policy entrepreneurs often play an important role in policy reform. They can come from anywhere, but most are policy insiders who have long played a role in the policy-making process.

- Policy entrepreneurs swim in a sea (Kingdon's metaphor) of three separate and independent streams: problem recognition, generation of policy proposals, and political events. In short, problems, policies, and politics.

- These three streams meet in decision windows that open and close continuously and constitute unique opportunities for problem-solving. The chief role of the policy entrepreneur is to know when a window has opened and to act based on that knowledge.

- Because they take place within the flow of three autonomous streams, most policy processes are highly uncertain and unpredictable.

The characterization of three streams that flow freely in a sea of policy brilliantly specifies Machiavelli's fortuna. Virtu is interpreted by Kingdon as the substantive knowledge, willingness to act, and strategic and tactical skill of the policy entrepreneur. His theory of action is completed with the addition of the concept of a decision window that connects the virtu-possessing actor with fortuna in the form of the three streams.

For Indonesia, the governance scholar Sofie Schuette has written an excellent analysis of the important law creating the KPK, passed in December $2002 .{ }^{49}$ The KPK is generally regarded, both inside and outside Indonesia, as an example of a relatively successful anti-corruption commission. It reduces political inequality in at least two ways: by shrinking the amount of money available as a political resource to the small number of actors who are caught; and by dissuading many others from engaging in corrupt acts for fear of being punished. The first consequence is, of course, the most easily demonstrable by analysts. The second is less obvious and requires further research, perhaps through surveys and interviews of officials and business people.

\footnotetext{
${ }^{48}$ John W. Kingdon, Agendas, Alternatives, and Public Policies (New York, NY: Longman, 1995 [first published in 1984]).

${ }^{49}$ S. A. Schuette, "Against the Odds: Anti-corruption Reform in Indonesia," Public Administration and Development 32,1 (2012): 38-48.
} 
Schuette does not refer directly to Kingdon's book, but we can describe her argument in his frame. Schuette's actors, including donors and foreign consultants, were all visible. Reformasi opened a decision window, but the process was still slow. Before the 1999 election, several members of the New Order-era DPR (Dewan Perwakilan Rakyat, People's Representative Council) promoted the establishment of the KPK for electoral purposes but failed to enact it. From then until 2002, the most important role was played by the DPR, especially members of the steering committee. Donor influence was limited. "Rather than being a foreign legal transplant, the KPK was the result of a commonly perceived solution among Indonesian and international reformers to Indonesia's problem of enforcing its anti-corruption legislation." ${ }^{50}$

From Kingdon's point of view, the passing of the KPK law is a clear example of the resolution of a significant problem. His three streams-problem, policy, and politicsflowed separately and only came together in December 2002. The process was uncertain and unpredictable. Several policy entrepreneurs in the DPR played important roles in determining the final outcome. The decision window that was only opened prior to the 1999 election after being closed for decades was also crucial.

Djayadi Hanan's analysis of Indonesian legislative-executive relations during the SBY presidency is also very much in the Kingdon spirit. ${ }^{51}$ Hanan's frame is based on the most recent comparative-politics literature on presidential governments with multiparty systems, a combination that has been considered prone to instability and gridlock, especially in Latin America. His Indonesian cases are organized in three categories: annual state budget decisions; six cases of specific legislation (the election law, the freedom of information law, the law on governmental ministries, the law on national and local legislatures, the election implementation law, and the law establishing social security implementing institutions); and three cases of legislative oversight (the Bank Century scandal, fuel oil subsidies, and corruption in tax collection).

Hanan's first finding is that the president and the DPR are about equal in their formal constitutional powers. This assessment challenges Jakarta public discourse, in which the conventional wisdom since the 2002-04 constitutional amendments has been that the DPR is more powerful than the president. Hanan's second finding is that, measured in terms of the results of the deliberative process, there are no signs of gridlock. After SBY became president, a budget has been passed every year. The same is true for the six substantive bills. The oversight cases of Bank Century, the fuel oil subsidy, and tax corruption all ended with compromises accepted by the president and the DPR. In short, according to Hanan, the Indonesian case represents an example of executive-legislative relations in a multiparty system that has "apparently performed reasonably well." ${ }^{52}$ It has also arguably reduced political inequality by making the political process more transparent, increasing the role of legislators, and raising the ability of the executive to formulate and implement policies that promote the public welfare.

\footnotetext{
${ }^{50}$ Schuette, "Against the Odds," p. 43.

${ }^{51}$ Djayadi Hanan, Making Presidentialism Work: Legislative and Executive Interaction in Indonesian Democracy (PhD dissertation, Department of Political Science, Ohio State University, 2012).

${ }^{52}$ Ibid., p. ii.
} 
What factors explain this success? Hanan highlights several institutions, formal and informal, that pressured the two sides to compromise in order to achieve their separate goals. Some examples: constitutionally mandated deliberation and agreement requirements from beginning to end of each legislative process; long-standing personal relationships, predating the Yudhoyono government, between presidential and DPR staff; and collective internal organization and decision-making structures in the DPR (in the form of caucuses, commissions, and committees). Hanan proposes that gridlock occurs more often in the US Congress because it is a much more individualistically structured institution than the collectivist DPR.

Hanan also mentions culture as a causal factor, citing a general Indonesian tendency to be accommodative and look for mufakat, consensus. No less important, he praises the conscious choices of President Yudhoyono and leaders of other parties to form coalitions. "Finally, the problem of a minority president with minority legislative support (low partisan power) is overcome by the existence of a coalition. This study finds that the coalition has been working in mitigating immobilism and deadlock in legislative-executive relations in multiparty presidentialism comparable to most multiparty presidentialism systems in Latin America in the last two decades." ${ }^{53}$

The fourth and final action theorist is Richard Samuels, a leading Japan specialist at the Massachusetts Institute of Technology and author of Machiavelli's Children: Leaders and their Legacies in Italy and Japan. ${ }^{54}$ Like Kingdon, Samuels attempts to explain the causes and consequences of important policies. Where Kingdon limited himself to the United States and one presidential administration, however, Samuels's wide canvas covers the history of Italy and Japan as late modernizers. For Samuels, the success of modernization and its special qualities in Italy and Japan were caused by policy choices made by twenty-four leaders, eleven in Italy and thirteen in Japan. Those choices were intentional and consequential, though constrained by social forces. The leaders he studies were involved in nine important cases of decision-making that Samuels presents in parallel analyses to highlight his comparative argument.

The first case is nineteenth-century state-building, liberal in Italy and authoritariannationalist in Japan. The key decision-makers were Count Camillo Benso di Cavour in Italy and Ito Hirobumi and Yamagata Aritomo in Japan. These three individuals, according to Samuels, shaped the substantive content of modern institutions in Italy and Japan. The other eight cases, presented chronologically, focus on economic development, the death of liberalism, the birth of corporatism, foreign alliances after World War II, controlling corruption, the impact of the death of communism in the Soviet Union and Eastern Europe, and the balance of authority between regions and the center. Samuels concludes that his actors possessed considerable freedom of action. $\mathrm{He}$ argues persuasively that, in each case, the leaders formulated goals, strategies, and tactics while weighing various alternatives. Morally and in the eyes of history, they were responsible for their choices.

Samuels's social forces derive from anthropology (culture), sociology (social structure), psychology (perception and cognition), and political science (governmental

\footnotetext{
${ }^{53}$ Ibid., pp. 406-7.

${ }^{54}$ Richard Samuels, Machiavelli's Children: Leaders and their Legacies in Italy and Japan (Ithaca, NY: Cornell University Press, 2003).
} 
and political institutions). They are treated analytically as both constraints that obstruct and resources that facilitate political action. Quoting Samuels: "leadership is that constrained place where imagination, resources, and opportunity converge." ${ }^{55}$

Beyond the soaring rhetoric, Samuels offers three practical contributions to a theory of action. First, he describes three mechanisms of mobilization used by political actors to achieve their goals: buying, bullying, and inspiring. Citing a key term of Machiavelli's, the author explains that these mechanisms specify dimensions of virtu. Each mechanism is connected by Samuels to several commonly encountered political resources: in buying, actors seek money, goods, services, and positions; in bullying, coercion and violence are employed by state institutions like the police and the armed forces and by social groups outside the state; for inspiring, actors rely on ideology, symbolic policies, and other resources that have to do with affect, legitimacy, or culture.

Samuels's three-element model can be used to analyze leadership successes and failures. In Indonesia, the perdurance of the New Order can be explained as a result of the mobilization of all three mechanisms in shifting combinations, depending on the situation and needs of Suharto, the primary actor. ${ }^{56}$ At the beginning, the primary mechanism was bullying. The army was used to destroy the communist party and control other political forces. Golkar's victorious 1971 election campaign was also guaranteed by armed force. After that, buying became more important, in the narrow (and democratically illegitimate) sense of corruption, but also the broader (and democratically legitimate) sense of economic development that created the foundations of broad prosperity. As Dahl predicted, this prosperity ultimately reduced political inequality by distributing more widely resources of wealth, knowledge, social status, and organizational skills. Post-reformasi, these resources are available to political actors throughout the system. Returning to the New Order, from beginning to end inspiring mechanisms were also deployed, for example, in the form of anti-communism, antiIslamism, and, of course, the promotion of the state doctrine of Pancasila, an allpurpose, all-period ideology.

Samuels's emphasis on the role of legacy as the chief constraint for the next generation of leaders is also useful. In the case of Indonesia, scholars who write about the reformasi period must weigh carefully the impact of important decisions made by previous governments, perhaps extending back to precolonial times, while realizing that legacies represent only constraints, not determinants or causes.

An obvious example of a legacy, with great promise for reducing political inequality, is today's governmental decentralization, which has channeled authority primarily to districts and municipalities rather than to provinces. This reform was powerfully influenced by Indonesian nationalist aversion to Dutch-imposed federalism in the $1940 \mathrm{~s}$ and to separatist and perceived separatist movements in the 1950s. Another example is the preference for presidentialism over parliamentarism. This inclination is traceable to the instability of the 1950s multiparty parliamentary system as perceived by national politicians during the democratic transition in the late 1990s

\footnotetext{
${ }^{55}$ Ibid., p. 6.

${ }^{56}$ R. William Liddle, "Indonesia: A Muslim-Majority Democracy," in Comparative Governance, ed. W. Phillips Shively (New York, NY: McGraw-Hill PRIMIS, 2007), paging various.
} 
and early 2000s. A third legacy, perhaps less obvious and more controversial, is the debt owed by democrats to Suharto's electoral institutions, designed to legitimize a dictatorship. These turned out to be readily usable with only minor adjustments for the first genuinely democratic elections in 1999, enabling the country to postpone more contentious constitutional reform until the first democratic government had been created.

Finally, the concept of constraint-stretching may be Samuels's most useful contribution to measure the virtu or achievements of today's leaders. In Japan and Italy, success is almost always connected by Samuels to the capability of a leader to stretch the major constraints of his time. The highest accolades are awarded by Samuels only to the leaders who act in a way that is original, courageous, and unexpected by friends, enemies, and the outside world. Mere success is not enough.

Can the concept of constraint-stretching be applied to Indonesia? At the end of the 1980s, modernist Muslims were embraced by President Suharto after being ostracized for decades. The new policy startled many people, including the modernists and those who feared them, because Suharto had a well-deserved reputation for hostility to modernists only exceeded by his hostility to communists. After Suharto stepped down, we could see that his embrace had had a significant legacy impact, because all important religious groups now had a place at the national table as Indonesia democratized. Given the results of this highly significant and politicized case involving Muslims, there is now much more equality in the country than had been true during most of the Suharto period.

In 1998-99, new President Habibie made his own bold moves by initiating a promised democratic election, decentralizing authority to the regions, and offering independence to East Timor. All of those policies were his choices. If retired army General Try Sutrisno (vice president until March 1998) had become president instead, his choices would almost certainly have been different. After the 1999 election, Habibie failed to become Indonesia's first democratically elected president, but a genuine democratic transition and increase in political resources for most Indonesians had taken place during his term. Like Samuels's leaders in Italy and Japan, Habibie stretched his constraints and changed the history of his nation. After that, there has not been a president who tried, much less succeeded, in stretching constraints either to achieve personal goals or to enhance political equality significantly.

A final formulation of action theory that summarizes concisely the discussion so far is the following from the leftist sociologist Steven Lukes. In a seminal essay entitled "Power and Structure," Lukes discusses types of structural constraints confronted by political actors, including internal and external, positive and negative, and endsversus means-oriented constraints. He concludes that "Social life can only properly be understood as a dialectic of power and structure, a web of possibilities for agents, whose nature is both active and structured, to make choices and pursue strategies within given limits, which in consequence expand and contract over time." ${ }^{57}$

${ }^{57}$ Steven Lukes, "Power and Structure," Essays in Social Theory (New York, NY: Columbia University Press, 1977), Chapter 1, p. 28. 


\section{Conclusions}

Distributing political resources more equally is the greatest challenge facing modern democracies, if democracy is defined as political equality among all citizens, the definition of democratic theorist Robert Dahl. Unfortunately, this goal is difficult to achieve in capitalist market economies, which, ironically, constitute both a necessary condition for and a constant threat to modern democracy. In this, contemporary Indonesia is no different than any other democracy, past or present.

Karl Marx, who privileged class conflict as the dynamic force in history, launched a vigorous attack on capitalism in the nineteenth century. But Marx's followers in the twenty-first century do not help us much to understand how to improve democracy. The most prominent examples in Indonesian studies have been Richard Robison, Vedi Hadiz, and Jeffrey Winters. There are two fatal weaknesses in their approach. First, they denigrate or dismiss all resources other than great material wealth that might be mobilized to reduce political inequality. In their landscape, there are no more- and lessfertile uplands and lowlands but only one massive and desolate mountain range. Second-remarkably in the works of authors who represent the inheritors of a great revolutionary tradition-there is in their analyses no theory of political change, no specification of factors or processes that might reduce or replace the oppressive weight of material wealth. For well-wishers of democracy, theirs is truly a counsel of despair.

To construct a theory of political change, the sixteenth-century political thinker Niccolo Machiavelli is a better twenty-first-century guide than today's Marxists. To Machiavelli, the individual is an autonomous actor who self-consciously creates, possesses, and deploys political resources. In a modern democracy, this selfconsciousness is a necessary (though, of course, not sufficient) condition for holding elected leaders accountable. Most importantly, Machiavelli's concepts of virtu and fortuna offer a foundation for a new theory of action. Machiavelli's embryonic theory has, in turn, been brilliantly adapted to the needs of the twenty-first century by four prominent American political scientists: Richard Neustadt, James MacGregor Burns, John Kingdon, and Richard Samuels. Each of their frameworks can be applied productively to the analysis of contemporary democratic Indonesian politics.

Neustadt's focus on the presidential power to persuade as a political resource helps to explain the apparent gap between promise and performance in the presidency of Susilo Bambang Yudhoyono. It also enables us to understand better, for SBY as well as his successors, the role played by mass opinion surveys in holding presidents accountable to their electorates, an important dimension of political equality. Burns's distinction between transforming and transactional leaders gives us a tool to evaluate how successful previous presidents and other elected officials have been. It also sets a standard by which voters can judge future candidates for office. Less conventionally, Burns's concepts of followership and mutual engagement between leaders and followers can help explicate the growth and appeal of civil society organizations across a broad spectrum of issue areas, guiding research on organizations ranging from the KPK to Hizbut Tahrir Indonesia.

Kingdon-style systematic empirical analysis of the causes of policy outcomes has already yielded valuable studies of the formation of the corruption-fighting KPK and of the relative success of executive-legislative relations during the SBY presidency, 
both of which have had a positive impact on political equality during the reformasi period. Samuels's three mechanisms of political mobilization (buying, bullying, and inspiring) have already been employed to explain the perdurance of Suharto's New Order. His concept of legacy gives us a deeper understanding of today's governmental decentralization, the choice of presidentialism over parliamentarism, and the positive role for political equality played by Suharto's electoral institutions in the democratic transition. Finally, President Habibie truly stretched constraints by conducting a genuinely democratic election, decentralizing governmental authority, and offering independence to East Timor. Each of these actions undeniably enhanced and distributed more equally the quantity and quality of political resources in the hands of Indonesian citizens.

To conclude at a more foundational level, we need to remember Dahl's warning that increasing and distributing political resources to improve the quality of democracy is a Herculean task. A vast, probably growing, abyss separates the resourceful haves from the have-nots in Indonesia as elsewhere. But we can take heart in the knowledge that tools are available to attack this problem. If Indonesians do increase and distribute resources more equally in the twenty-first century, it may well be because they have developed a modern Machiavellian theory of action enabling them to do so. 